\title{
Mathematical Reasoning Abilities of High School Students in Solving Contextual Problems
}

\author{
Ainun Rahma Firdausy ${ }^{1}$, Triyanto $^{2}$, Diari Indriati ${ }^{3}$ \\ ${ }^{1}$ Postgraduate Program of Mathematics Education, Universitas Sebelas Maret, Surakarta, \\ Indonesia \\ ${ }^{2,3}$ Universitas Sebelas Maret, Surakarta, Indonesia \\ Email: inunrahma29@gmail.com
}

\begin{abstract}
The purpose of this study was to describe students' mathematical reasoning abilities, such as: drawing conclusions from a statement, doing mathematical manipulation, providing valid arguments and presenting mathematical statements, both verbally and in writing, in the form of pictures or graphs. This research used the descriptive qualitative method. The instruments used in this study were the main instrument (researchers) and the supporting instruments (tests and interviews). The test was given to 25 students of class XII SMA Muhammadiyah Surakarta Special Program (Muhammadiyah Surakarta Senior High School Special Program). The subjects of this study were eight students of class XII who were selected by purposive sampling technique. The results showed that students had good mathematical reasoning skills while doing mathematical manipulations and presenting mathematical statements verbally, in writing, or in pictures. Students did not show good mathematical reasoning skills when students have to draw conclusions from a statement and provide valid arguments. This is because students still do not master how to identify and determine the right strategy to solve problems, and the answers given by students were still not correct. In the future, teachers are expected to provide problems (questions) in various mathematical reasoning, so students are accustomed to working on problems with various levels of mathematical reasoning, and students' mathematical skills can be better trained.
\end{abstract}

Keywords: Argument, Mathematical Manipulation, Mathematical Reasoning, Conclusion.

\section{A. INTRODUCTION}

Mathematics is one of the basic education that is considered important in life. The purpose of mathematics education is to produce students who have skills in solving problems and foster high interest and motivation in studying other subjects that use mathematical principles (Riastuti et al., 2017). Ironically, based on the Program for International Student Assessment (PISA) in 2018, it is known that the mathematics ability of Indonesian students has decreased compared to 2015, from a score of 397 to 386. Indonesia is also in the lowest position based on the results of the TIMSS (Trends in International Mathematics and Science Study) 2015, Indonesia is ranked 44th out of 49 countries, with an average score of 397 while the international average score is 500 (Hadi \& Novaliyosi, 2019). In addition, a similar case also occurred in one high school in Indonesia, the average score of the 2019 national exam at the Muhammadiyah Surakarta Senior High School Special Program in mathematics was 36.39. This shows that their score was still below the minimum 
passing criteria. Low student learning outcomes in mathematics are an indication that the objectives of learning mathematics and students' conceptual understanding in solving problems have not been achieved optimally..

The development of mathematics learning must form students' mindsets that can be measured by their abilities. One of the abilities that can form a mindset is mathematical reasoning ability (Hidayat et al., 2018). The reasoning is one of the abilities that become the foundation for thinking mathematically (Loong et al., 2014). Mathematical reasoning is the process of deducing problem-solving from a given problem (Bergqvist, 2007). The important role of reasoning skills for students is so that students can solve mathematics problems more easily (Permana \& Utari, 2007). Besides, reasoning can help students to express arguments to understand mathematics (Ayal et al., 2016). It is described in the results of PISA (2018) that to be successful in the PISA test, students must be able to reason mathematically and be able to use concepts, procedures, facts and tools in mathematics to describe, explain and predict a phenomena.

The stages of mathematical reasoning in The National Council of Teachers of Mathematics (NCTM) include: (a) analyzing problems; (b) implementing strategy; (c) seeking and using relationships between different mathematical domains, different contexts, and different representations; (d) reflecting a solution to a problem (Mathematics, 2000). Based on this, reasoning becomes a basic ability that is needed by students to be able to improve general mathematics skills.

Reasoning is one of the basic skills of mathematics which will continue to be a hot issue in the future (PISA, 2015). Several studies have revealed the low achievement of Indonesian students' mathematical reasoning, one of which was revealed by Arwinie (2014) which stated that out of 40 junior high school students, only one student was able to answer with a good level of reasoning. Wardani and Rumiati (2011) says that reasoning is not the maximum could be due to a lack of imagination and creativity of the students. Reasoning is not only a basic mathematical skill but also an ability that requires students to think comprehensively. Student obstacles in achieving good reasoning include the lack of ability to analyze, generalize, integrate, give reasons and solve non-routine problems (Rizta et al., 2013). Characteristics of students' mathematical reasoning are still heavily influenced by imitative reasoning, that is the difficulties faced by students in implementing routines in daily learning (Sukirwan et al., 2018)

Therefore, the purpose of this study was to describe the mathematical reasoning abilities of class XII students at SMA Muhammadiyah Surakarta Special Program (Muhammadiyah Surakarta Senior High School Special Program). By knowing the profile of students' mathematical reasoning abilities, it is hoped that it can provide information to teachers to find out the level of student characteristics in order to improve students' mathematical reasoning abilities in the future. 


\section{B. METHOD}

The type of research used in this research is descriptive qualitative which produces descriptive data in the form of explanations/descriptions of students' mathematical reasoning abilities in solving contextual questions. The instruments used in this study were the main instrument (researchers) and supporting instruments (tests and interviews). The test was given to class XII students of Muhammadiyah Surakarta Senior High School Special Program. Based on the results of the students' answers, the answers from two students were selected for each indicator which could provide a lot of information about each indicator, so that it could be studied more deeply. Two students were selected based on the purposive sampling technique for interviews. The results of the analysis from the answer sheets and interviews were then compared to determine the validity of the data.

The test given consisted of four questions, each of which is based on indicators of mathematical reasoning. The question items given have passed the validation process by experts and are stated as questions that can be used to measure the mathematical reasoning abilities of high school students. The indicators used as a reference for analyzing mathematical reasoning abilities are: 1) drawing conclusions from a statement, 2) performing mathematical manipulation, 3) providing valid arguments, 4) presenting mathematical statements verbally, in writing, pictures or graphics.

\section{RESULTS AND DISCUSSION}

The research results were obtained based on the results of the students' mathematical reasoning ability tests. The test is in the form of a contextual description which consists of four questions, one question contains an indicator that must be achieved. The following descriptions are the results of the analysis of student work.

\section{Problem 1: Drawing Conclusions from a Statement}

For the questions for problem 1, all the information needed to answer the questions has been presented and students only need to use simple mathematical operations. The following questions are presented in Figure 1.

Question 1: During recess the students were playing marbles. Nina then arranges the white and black marbles to forma pattern. The pattern is formed as shown below.

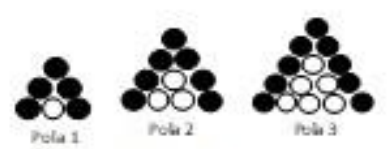

In the first pattern there are five black dots, in the second pattern there are seven black dots and in the third pattern there are nine black dots. Help Nina to find the number of black circles in the 10th, 30th and nth patterns.

Figure 1. Mathematical Reasoning Question 1 
The problem in Figure $\mathbf{1}$ is that students must look for the number of black dots in the 10th, 30th and n-th patterns, to overcome this problem, students must look at known patterns then operate them until they get the black circle pattern they are looking for.

Based on data analysis, almost all subjects were less careful in identifying information on the questions. Some subjects who were able to identify information and answer questions coherently, were wrong when making inferences about the many nth black circle patterns. There are also subjects who count the total number of dots (black circles and white circles) even though what is meant in the problem is only the number of black dots. Although almost half of the subjects were not correct in answering and making conclusions, there were three subjects who were able to answer questions in the right way and had a structured sequence of steps. In addition, these three subjects can draw the right conclusions from the questions in

Figure 1. The following is examples of representative answers from the incorrect answer and correct answer.

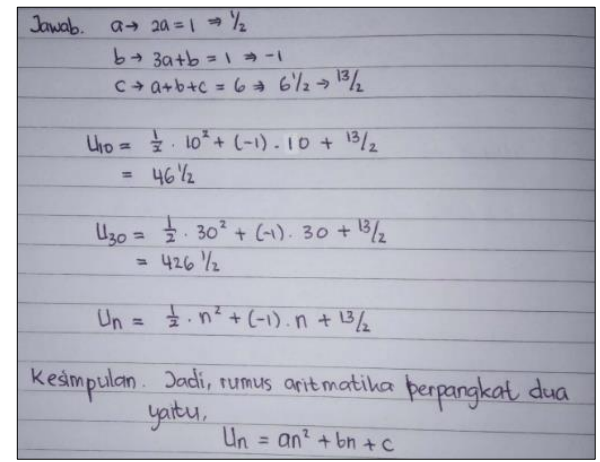

Figure 2. Incorrect answer

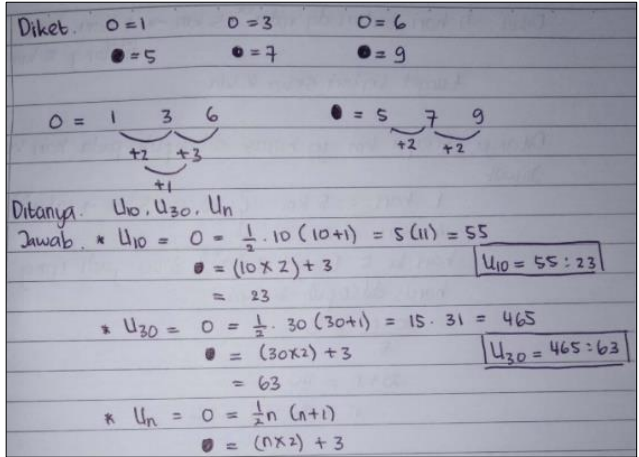

Figure 3. Correct Answer

In Figure 2, it can be seen that the subject combined the calculations between black circles and white circles, which then also affected the final result of calculating the number of patterns. Even when drawing conclusions, the subject only wrote the formula. The subject did not really understand the meaning of the problem, but only memorizes the arithmetic formula to the square. This agrees with research from Sukirwan et al (2018) which states that the characteristics of mathematical reasoning are still heavily influenced by imitation / memorization reasoning. The results of the interview also showed that the subject did not read and understand the questions in detail, the subject was focused on answering the questions quickly and did not double-check the results.

Whereas in Figure 3, the subject seems to have separated the calculation between the number of black and white circles from the beginning. And it is also supported by the accuracy of the subject's calculation of the number of black circles to the 10th, 30th and n-th. In line with the results of the interview, it showed that the subject can clearly understand the information presented on the questions. The subject was also able to solve the problem easily according to the stimulus on the question. 


\section{Problem 2: Doing Math Manipulation}

The question for problem 2 is classified as a question with a moderate level of reasoning, where there is initial information, and to answer this question, students need to manipulate the available information. The question is presented in Figure 4.

Question 2: To prepare for the running competition at school,
Siska regularly runs around the field around her house every
morning. For 4 consecutive days, Siska was able to run an
average of $5 \mathrm{~km}$ / day. However, Siska has a target to be able to
run as far as $8 \mathrm{~km}$. How many km that must be taken Siska on
day 5 so that the target can be achieved?

Figure 4. Mathematical Reasoning Question 2

The problem in Figure 4 is that students have to find the remaining distance that must be covered on the fifth day in order to meet the target. To solve this problem, students must be able to manipulate the information available on the question. Based on data analysis, almost all subjects can identify the information contained in the questions and use routine procedures to solve them. Mostly subjects used the value comparison method, then looks for the difference, the other uses the example with the variable $x$, then operated with basic mathematical operations. Although most subjects answered correctly and were able to solve it by manipulating information, there were also subjects who were not careful when understanding the meaning of the questions. The following are examples of inaccurate and incorrect answers, as well as accurate answers.

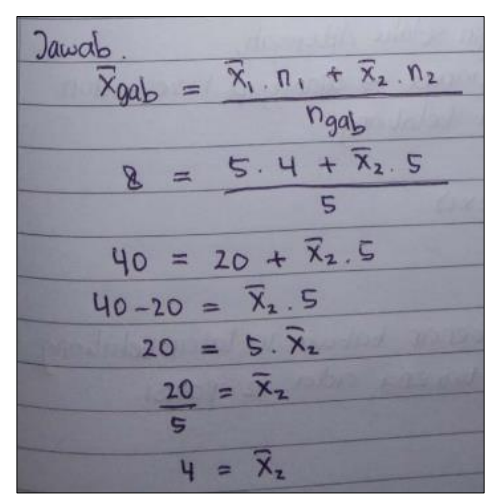

Figure 5. Inaccurate answer

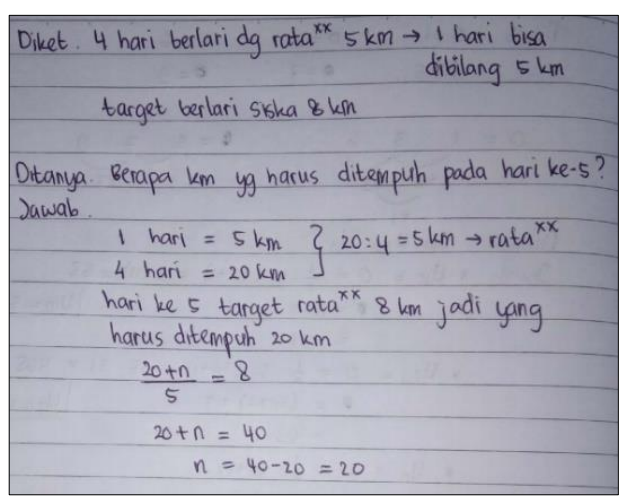

Figure 6. Accurate answer

In Figure 5, subject successfully completed using the combined average strategy, but the subject made a mistake when substituting the known value into the formula, as a result, the final calculation was incorrect. The results of the interview also revealed that the subject did not read the questions carefully, the subject admitted that she did not understand the meaning of "how many kilometers to travel on the fifth day?". In Figure 6, subjects successfully solved the problem to answer questions in a structured sequence of steps and the right. The subject appeared to be using two steps of completion, the first step is to use comparisons, and in the next step, the subject represents the distance that has to be covered on the fifth day with " $n$ ". During the interview with the subject, it was revealed that the 
subject had been able to understand the information presented clearly and in detail and the subject had no difficulty when expressing arguments verbally related to the strategy she chose.

\section{Problem 3: Provide Valid Arguments}

The question for problem 3 related to the student's ability to provide arguments regarding the chosen strategy. The form of the problem is presented in Figure 7.

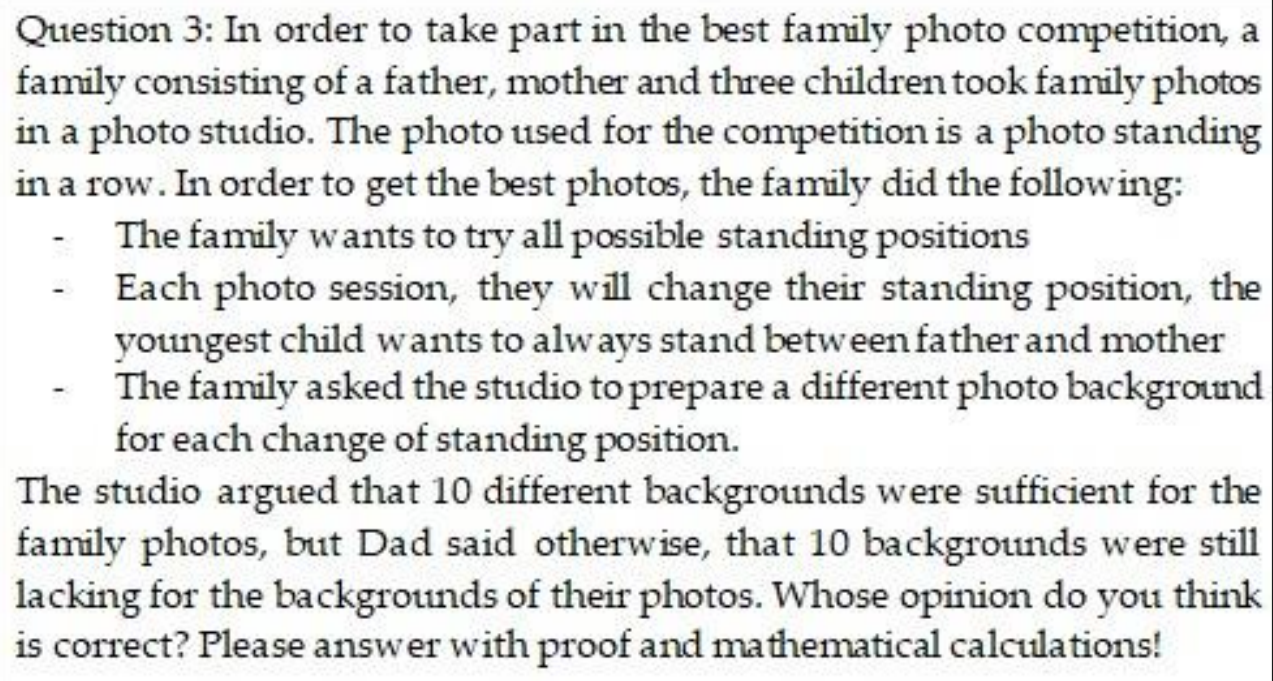
youngest child wants to always stand between father and mother

- The family asked the studio to prepare a different photo background for each change of standing position.

The studio argued that 10 different backgrounds were sufficient for the family photos, but Dad said otherwise, that 10 backgrounds were still lacking for the backgrounds of their photos. Whose opinion do you think is correct? Please answer with proof and mathematical calculations!

\section{Figure 7. Mathematical reasoning question 3}

Question in Figure 7 is that students must find whose opinion is more appropriate, whether the opinion of the studio or the opinion of the father. In addition, students were asked to provide arguments for why they chose this answer. Based on data analysis, almost all subjects were unable to identify the information contained in the questions, resulting in errors when answering. Most of the subjects failed to understand that there was a keyword in the question, namely "the youngest child always stands between father and mother", so they solved it by using the concept of enumeration rules and ignoring the keyword. Even so, there were three subjects who managed to answer with coherent steps and provide valid arguments to strengthen their answers.

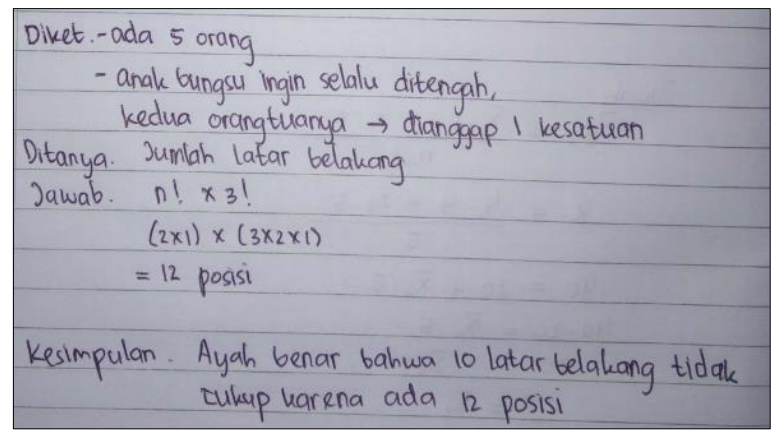

Figure 8. The Correct Answer

In Figure 8, subject can identify what information is contained in the problem and the subject can solve the problem appropriately. The subject succeeded in 
finding the keyword "the youngest child wants to always be between father and mother" so that the subject made father and mother become one unit. This made the subject implemented the problem correctly into the enumeration rules. Based on the results of the interview, the subject argued that the father's opinion was correct. From the calculation of the subject, it is found that there are 12 different standing positions, so if only 10 backgrounds are available it is not enough to make each standing position different. The subject said that it took him/her longer to find the right answer than the previous numbers.

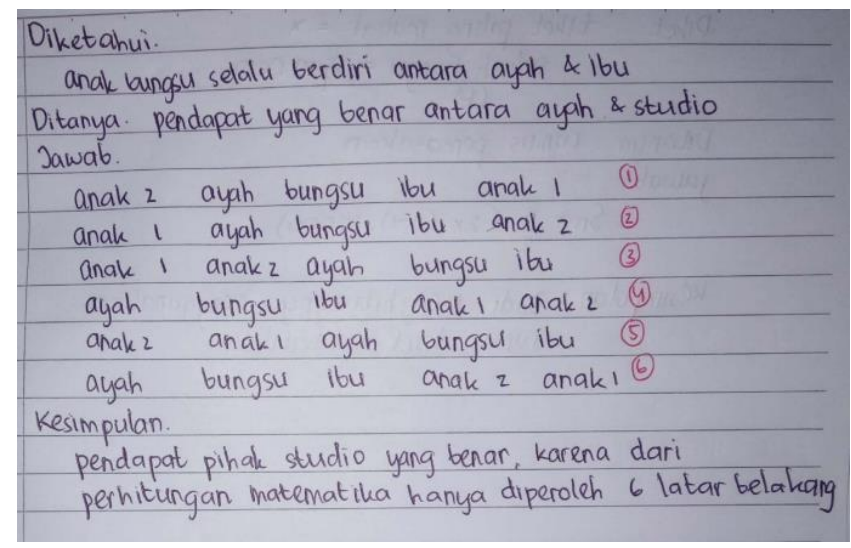

Figure 9. The incorrect answer

In Figure 9, subject can identify keywords and describe possible standing positions during family photos appropriately. However, at the time of the translation, it appears that the subject is less precise. It is correct that the subject gives the position of the youngest child always is between father and mother, but also true if the position the youngest child is between the mother and father. The subject only focuses on the position of the father, youngest child and mother, so the resulting number of standing positions is not quite right. Based on the interview, the subject does not think that the position of the mother, the youngest child and the father is also true. In fact, in Figure 9, it can be seen that at the time of work, the subject understood and described in detail the standing position of the family photo. The subject said that after doing it did not re-examine the results of his work.

\section{Problem 4: Present Math Statements Verbally, in Writing, Pictures or Graphs}

The question for problem 4 related to the student's ability to present a written statement of the available contextual problem (verbally, in writing or in pictures). The questions for the fourth problem are presented as in Figure $\mathbf{1 0 .}$

Question 4: Seating in a circular theater art which consists of six lines. The
number of seats in the first row is 25 seats, the second row is 35 seats, the
third row is 50 seats, the fourth row is 70 seats and so on. The most expensive
ticket prices are in the first row seats. If the difference in ticket prices
between two adjacent rows is IDR 10,000 and it is assumed that all audience
seats are full, the income will be IDR $22,500,000$. Express the inputs obtained
in the numerical equation! (most expensive ticket price $=x$ )

Figure 10. Mathematical reasoning question 4 
In Figure 10, students were asked to express the outcome into a numerical equation. To solve it, students must describe the information contained in the questions. Then, students implemented the concept of sequences to solve the problem in Figure 10. Based on data analysis, almost all subjects can identify the information contained in the questions, and not only write it in the form of a numeric equation, but also determine the most expensive and cheapest ticket prices. Examples of correct and incorrect answers to this problem are provided in Figure 11 and Figure 12.

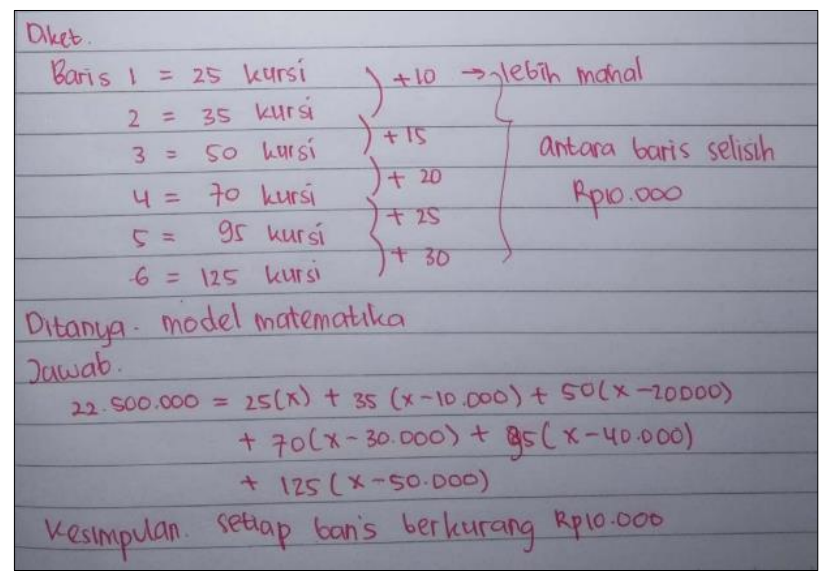

Figure 11. Correct answer

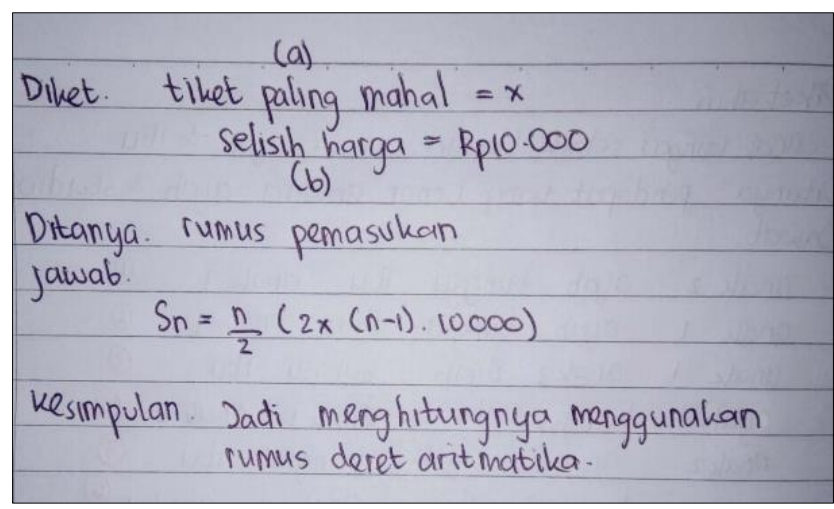

Figure 12. Incorrect answer

In Figure 11, subject has succeeded in presenting a written statement in the form of a mathematical model correctly. The subject managed to understand every information and keywords in the questions. To answer mathematical model problems correctly, the subject must first describe the rows of chairs and make the difference in ticket prices clearer, after that, create a mathematical model using the variable $\mathrm{x}$ as the most expensive ticket price. During the interview, the subject said in detail the steps of how he found the mathematical model as on the answer sheet. The subject said that he had problems in solving the problem, because the problem was a story question, but he did not give up and read repeatedly to understand the meaning of the problem in Figure 10.

In Figure 12, the subject shows that she was not meticulous enough when choosing the settlement strategy. Besides, the subject also directly used the 
arithmetic series formula without describing what information is contained in the problem. During the interview, the subject admitted that she had difficulty in understanding the available information, because the questions were too long. The subject only obtained the keyword that the difference in ticket prices was IDR 10,000. Because of this, the subject also cannot meet the indicators, namely presenting a written statement of the available problems.

Based on the results of the explanation on each problem, from problem 1 to problem 4, it was found that most students could not meet the first and third indicators. The difficulty of students in the first indicator (drawing conclusions from a statement) is triggered by students' inaccuracy when identifying initial information and questions, which then resulted in errors in drawing conclusions. This strengthens the opinion of Maryati (2017) that one of the difficulties felt by students was drawing conclusions, which is influenced by the factor of students' lack of understanding of the material. Most students rushed to find answers and did not reexamine the results of their work. Meanwhile, the difficulty of students in the third indicator (giving valid arguments) is that students were not used to giving reasons for the decisions they made. In addition, most of the subjects also experienced the same difficulties as the first indicator, it was difficult to identify the information on the questions. This is in line with the findings of previous research which stated that most students have difficulty understanding the sentences in the questions and implementing the solving strategies (Seifi, et al., 2014). In other studies, it was found that argumentation skills can develop well if students have a good understanding of concepts (Squire \& Mingfong, 2007). By having good argumentative skills, it can improve students' cognitive abilities, especially in the aspect of understanding (Kuhn, 2010) and also train higher-order thinking skills (Akarsu, et al., 2013), especially in reasoning skills.

\section{CONCLUSION}

Based on the results and analysis, it was found that only $12.5 \%$ of students were able to meet the indicators of drawing conclusions from a statement, while $87.5 \%$ of students could not fulfill the indicators of drawing conclusions from a statement. $6.67 \%$ of students met the indicators of performing mathematical manipulation, while $33.33 \%$ of students did not fulfill the indicators of performing mathematical manipulation properly. As many as $12.5 \%$ of students were able to meet the indicators of giving valid arguments, while $87.5 \%$ of students did not meet the indicators of providing valid arguments. $62.5 \%$ of students were able to fulfill the indicators of presenting written or oral mathematical statements properly, while $37.5 \%$ of students did not fulfill the indicators of presenting written or oral mathematical statements properly.

The results showed that the students of class XII at Muhammadiyah Surakarta Senior High School Special Program could fulfill mathematical reasoning abilities on indicators of performing mathematical manipulation and presenting written or oral mathematical statements properly. However, students were not good at solving 
problems related to drawing conclusions and proposing valid arguments. This is because the students' ability to identify and determine problem-solving strategies is still not good, so, the answers are not correct. In the future, teachers are expected to provide mathematical reasoning questions in various forms, so that students are trained to work on problems with various levels of mathematical reasoning and students' mathematical skills will be better, especially in the ability to draw conclusions and provide valid arguments.

\section{REFERENCES}

1. Akarsu, B., Bayram, K., Slisko, J., \& Cruz, A. C. (2013). Understanding Elementar Students' Argumentation Skills through Discrepant Event "Marbles in the Jar". International Journal of Scientific Research in Education, 6(3), 221-232.

2. Arwinie, N. (2014). Kemampuan Penalaran dan Komunikasi Matematis serta SelfConcept Siswa MTS.

3. Ayal, C. S., Kesuma, Y. S., Subandar, J., \& Dahlan, J. . (2016). “The Enhancement of Mathematical Reasoning Ability of Junior High School Students by Applying Mind Mapping Strategy". Journal of Education and Practice.

4. Bergqvist, E. (2007). Types of reasoning required in university exams in mathematics. Journal of Mathematical Behavior, 26(4), 348-370. https://doi.org/10.1016/j.jmathb.2007.11.001

5. Hadi, S \& Novaliyosi. (2019). TIMSS Indonesia (Trends in International Mathematics and Science Study). Prosiding Seminar Nasional \& Call Paper Program Study Magister Pendidikan Matematika Universitas Siliwangi. Tasikmalaya: Universitas Siliwangi.

6. Hidayat, W., Wahyudin, \& Prabawanto, S. (2018). Improving Students' Creative Mathematical Reasoning Ability Students through Adversity Quotient and Argument Driven Inquiry Learning. Journal of Physics: Conference Series, 948(1). https://doi.org/10.1088/1742-6596/948/1/012005

7. Kementrian Pendidikan dan Kebudayaan. (2018). Pendidikan di Indonesia Belajar dari Hasil PISA 2018. Jakarta: Pusat Penilaian Pendidikan Balitbang Kemendikbud.

8. Kuhn. (2010). Teaching and Learning Sciences as Argument. Wiley Periodicals, Inc. Sci Ed, v(94). 810-824.

9. Loong, E., Vale, C., Bragg, L., and Herbert, S. (2014). Primary School Teacher's Perception of Mathematical Reasoning. Proceedings of the Thirty Seventh Annual Conference of the Mathematics Education Research Group of Australasia (pp.466-472). Melbourne: MERGA.

10. Maryati, I. (2017). Analisis Kesulitan dalam Materi Statistika ditinjau dari Kemampuan Penalaran dan Komunikasi Statistis. Prisma, 6(2), 173-179. https://doi.prg/10.35194/jp.v6i2.209

11. Mathematics, N. C. of T. of. (2000). Principles and Standards for School Mathematics.

12. Permana, Y \& Utari, S. (2007). Mengembangakan Kemampuan Penalaran dan Koneksi Matematik Siswa SMA melalui Pembelajaran Berbasis Masalah. Jurnal 
Educationist, Vol. 1, No.2, Juli 2007, hlm. 116-123.

13. Riastuti, N., Mardiyana, M., \& Pramudya, I. (2017). Students' Errors in Geometry Viewed from Spatial Intelligence. Journal of Physics: Conference Series, 895(1). https://doi.org/10.1088/1742-6596/895/1/012029

14. Rizta, A., Zulkardi, Z., \& Hartono, Y. (2013). Pengembangan Soal Penalaran Model TIMSS Matematika Smp. Jurnal Penelitian Dan Evaluasi Pendidikan, 17(2), 230-240. https://doi.org/10.21831/pep.v17i2.1697

15. Seifi, M., Haghverdi, M., \& Azismohamadi, F. (2014). Recognition of Students' Difficulties in Solving Mathematical Word Problems from The Viewpoint of Teacher. Journal of Basic and Applied Scientific Research, 2(3), 2923-2928.

16. Squire, K., \& Mingfong. (2007). Developing Scientific Argumentation Skills with a Place-Based Augmented Reality Game on Handheld Computers. Journal of Science Education and Technology, Vol. 16(1).

17. Sukirwan, Darhim, D., \& Herman, T. (2018). Analysis of students' mathematical reasoning. Journal of Physics: Conference Series, 948(1). https://doi.org/10.1088/1742-6596/948/1/012036 